\title{
Effects of Agricultural Encroachment and Drought on Wetlands and Shallow Lakes in the Boreal Transition Zone of Canada
}

\author{
S. E. Bayley • A. S. Wong • J. E. Thompson
}

Received: 22 February 2012 / Accepted: 23 October 2012/Published online: 21 November 2012

(C) The Author(s) 2012. This article is published with open access at Springerlink.com

\begin{abstract}
The ecoregions along the southern edge of the Boreal Plains have experienced rapid and extensive agricultural encroachment over the last 60 years. Over 200 wetlands and shallow lakes in central and northern Alberta and northeastern British Columbia, Canada were surveyed along an agricultural encroachment gradient to investigate the effect of land use on water quality between 2005 and 2007. Study wetlands were typically small (median $29.8 \mathrm{ha}$ ), shallow (median $0.8 \mathrm{~m}$ ) and highly eutrophic (median $148 \mu \mathrm{gTP} \mathrm{L}^{-1}$ ). Wetlands in the southern Boreal Plains were regionally variable and dynamic. Drought in 2006 caused significant increases in TP, TN, chlorophyll $a(\operatorname{chl} a)$, conductivity, silica and significant decreases in maximum depth and light penetration. Increased agricultural activity within a $1.6 \mathrm{~km}$ buffer surrounding wetlands enhanced nutrients but not chla concentrations or submersed aquatic vegetation (SAV) coverage. Wetlands with higher amounts of agriculture in the buffer zone tended to be shallower with decreased secchi depths. Due to shallow depths, SAV thrived even under hypereutrophic conditions with high agricultural encroachment in the buffer zone. Our study suggests that SAV has a significant role in maintaining clear water states in Boreal Transition Zone wetlands and shallow lakes through its ability to suppress concentrations of chla and TP.
\end{abstract}

Electronic supplementary material The online version of this article (doi:10.1007/s13157-012-0349-x) contains supplementary material, which is available to authorized users.

S. E. Bayley $(\bowtie) \cdot$ A. S. Wong

Department of Biological Sciences, University of Alberta,

Edmonton, AB, T6G 2E9, Canada

e-mail: sbayley@ualberta.ca

J. E. Thompson

Ducks Unlimited Canada,

17915-118 Ave,

Edmonton, AB, T5S 1L6, Canada
Keywords Shallow lakes · Depressional wetlands · Phosphorus · Algae $\cdot$ Submerged aquatic vegetation . Southern boreal marshes

\section{Introduction}

Conversion of native landscapes for agriculture has resulted in extensive loss of wetlands globally and in Canada (Turner et al. 1987; Watmough et al. 2002; Zedler and Kercher 2005; Dahl and Watmough 2007) as well as increased runoff of nutrients from agricultural lands (Harmel et al. 2006). Agricultural encroachment into forested catchments can increase runoff of nutrients and other ions into surface waters (Carpenter et al. 1998), including wetlands (Verhoeven et al. 2006). Increased runoff of nutrients has altered vegetation, biodiversity and productivity of wetlands (Zedler and Kercher 2005; Verhoeven et al. 2006). In Canada, agricultural and industrial development in the southern portion of the Boreal Plains ecozone is rapidly reducing and degrading the remaining forest cover and its associated wetlands and shallow lakes. Recent agricultural development in this region has been rapid and large scale with annual deforestation rates commonly ranging from $0.87 \%$ to $1.76 \%$ per year over the past three decades (Fitzsimmons 2002; Hobson et al. 2002). In particular, the Boreal Transition Zone (BTZ), generally defined as the southern tier of ecoregions in the Boreal Plains (Fig. 1), has suffered extensive wetland losses in recent decades (Watmough and Schmoll 2007). Much of this loss has occurred as forest land has been converted into production of annual crops, hayland, and improved pasture. The effect of agricultural conversion on nutrient status of shallow lakes and wetlands (hereafter collectively referred to as wetlands) has not been well studied in the BTZ. The region is unique in that background levels of nutrients are high in soils (Macrae et al. 
2005) and in undisturbed wetlands and shallow lakes (Prepas et al. 2001; Bayley and Prather 2003). The effect that agriculture may have on nutrient status of shallow open waters will be a complex function of water inputs such as surface and ground water inputs, infiltration rates, drainage patterns, deposition of windblown material and wetland buffer and landscape characteristics. There are substantial differences in hydrologic processes in wetlands associated with naturally forested landscapes versus cleared agricultural systems (van der Kamp et al. 2003; Devito et al. 2005a; Redding and Devito 2011) and it is likely that this will be reflected in the nutrient status and productivity of wetlands across a gradient of agricultural disturbance. Water in boreal wetlands is likely supplied primarily by summer precipitation and ground water discharge (Redding and Devito 2011); although in years of high precipitation intermittent flows can connect typically isolated basins (Devito et al. 2005a, b). Soil infiltration and storage of moisture appears to reduce surface runoff (Ferone and Devito 2004; Redding and Devito 2011), while forest cover inhibits windblown snow and accumulation of snow drifts which are characteristic of prairie pothole wetlands further south. Increasing cultivation near wetlands may lead to increased importance of surface water and nutrient runoff over frozen soils during the spring melt period, but the hydrologic impacts of agriculture are unknown. We expect that increased agriculture surrounding a wetland will result in increased nutrients in surface water despite limited evidence of surface water runoff in boreal landscapes.

Although studies have shown that agriculture can even affect the nutrient status of isolated depressional wetlands (Neely and Baker 1989; Whigham and Jordan 2003), other studies on seasonal prairie wetlands have shown that changes in water levels and vegetation structure are typically stronger determinants of nutrient dynamics (Detenbeck et al. 2002). We expect that drought and declining water levels will increase concentrations of nutrients and ions in northern wetlands. Numerous other factors, including climate, geology, topographic position, air borne sediment deposition and basin morphology also play an important role in controlling water quality of aquatic systems (Kratz et al. 1997; Devito et al. 2005b).

Increased nutrients, especially phosphorus, have increased the productivity and biomass of phytoplankton communities in fresh waters around the globe (Schindler 2006). We expect that biomass of the phytoplankton community in BTZ wetlands will increase due to the additional nutrients from agriculture. However in shallow lakes and wetlands, where submersed aquatic vegetation (SAV) can grow, the response of phytoplankton to additional nutrients is complex (Scheffer et al. 1993; Jeppesen et al. 2003; Zimmer et al. 2009). Increased concentrations of phytoplankton and the associated increases in algal turbidity often cause the loss of SAV due to increased shading (Scheffer et al. 1993; Carpenter et al. 1998; Jeppesen et al. 2003). However, shallow depths often allow light to penetrate permitting the growth of SAV. Furthermore, SAV provides several mechanisms that help decrease water turbidity and control suspended algal populations including 1) providing a refuge to zooplankton populations that graze on phytoplankton, 2) decreasing re-suspension of nutrient rich sediments, 3) shading, and 4) reducing nutrient availability in surface waters (Scheffer et al. 1993). The productivity of northern shallow lakes and wetlands can be dominated by either phytoplankton or by SAV (known as alternative stable states) (Jackson 2003; Bayley et al. 2007; Zimmer et al. 2009). We expect that with increased nutrient loading from agriculture, concentrations of chlorophyll $a$ [chl $a$ (representing algal biomass)] will increase and that abundance and density of SAV will decline due to shading.

The relatively recent agricultural expansion in the BTZ and the resulting conversion of mixed forest to pasture, hayland, or cropland, offers us the ability to contrast the nutrient characteristics of wetlands still embedded within large remnant tracts of native cover with those surrounded by varying amounts of agricultural encroachment. Our objectives for this study were to: 1) describe the physical and nutrient characteristics of BTZ wetlands over 3 years (including a dry year), 2) describe the effect of agricultural encroachment and drought on the nutrient status of wetlands and 3) contrast the effect of SAV relative to agricultural encroachment on chla and TP concentrations. We hypothesize that increasing agricultural encroachment surrounding wetlands and drier conditions would increase nutrient concentrations in surface waters. In response to increased nutrients from agriculture or evapoconcentration from drought, phytoplankton biomass (measured as chla concentration) will increase and SAV abundance will decrease.

\section{Methods}

Study Area The BTZ is located in the southern portion of Canada's Boreal Plains where most agriculture reaches its northern limits, and ranges from northeastern British Columbia to southern Manitoba (Fig. 1). Fifty-seven percent of the entire BTZ area $\left(\sim 34,000,000 \mathrm{~km}^{2}\right)$ is located within Alberta. Most of the wetlands included in this study $(88 \%)$ were in Alberta while a smaller number of wetlands (12\%) were included from the Peace Parklands in British Columbia. Overall, the BTZ is characterized by a subhumid low boreal ecoclimate with a mean summer temperature of $14{ }^{\circ} \mathrm{C}$ and mean winter temperature of $-13.5^{\circ} \mathrm{C}$. Annual precipitation is approximately $450 \mathrm{~mm}$ (Environment Canada 2007).

Wetlands are a common feature across the BTZ and the ones studied in this project can be generally classified as permanent and semi-permanent shallow open water and marshes (National Wetlands Working Group 1997). Relief is generally low with low-lying valleys and rolling plains with most study wetlands lacking permanent inflow or outflow streams. Geologically 


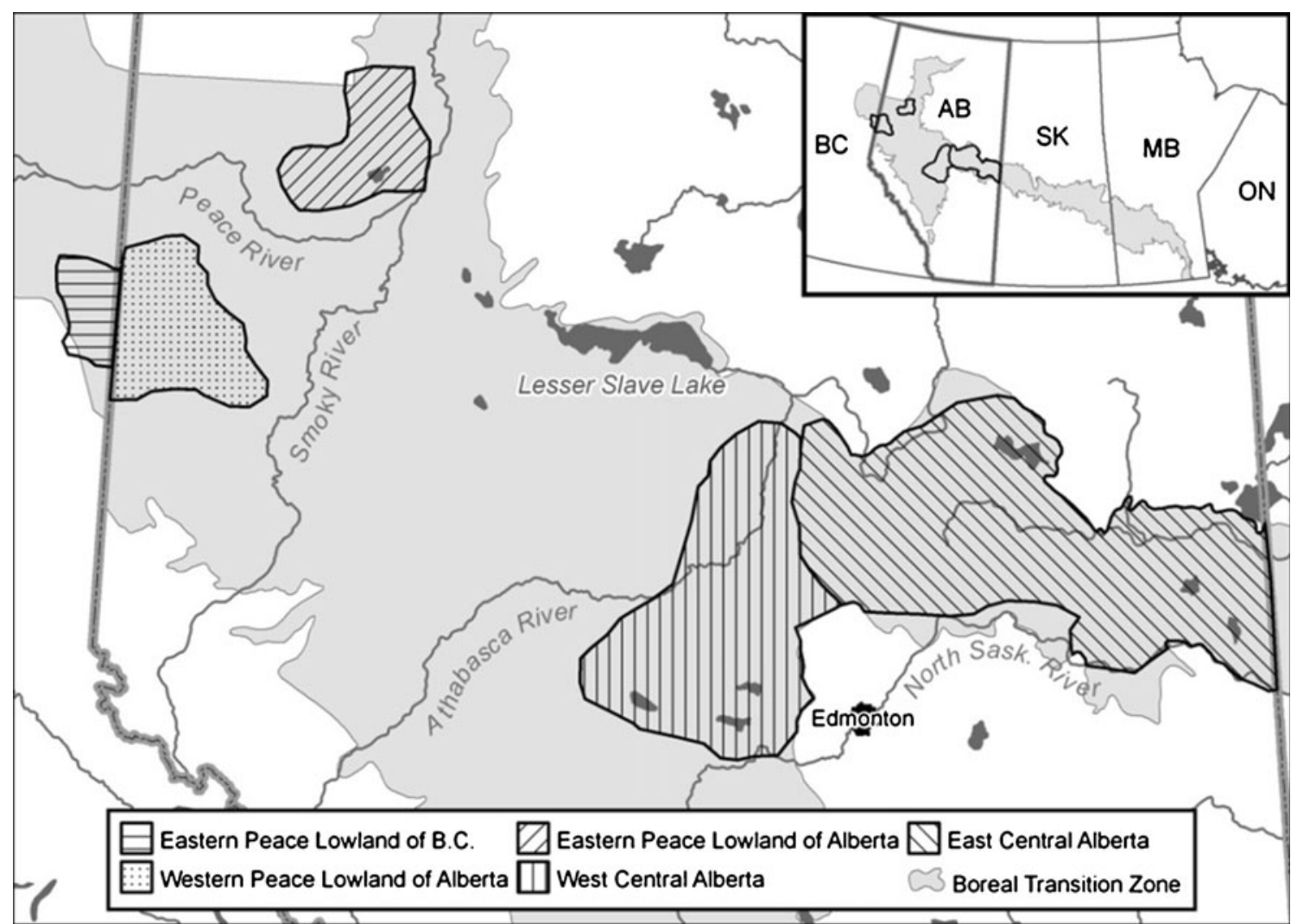

Fig. 1 Map of the Boreal Transition Zone study regions in Alberta and northeastern British Columbia, Canada. Inset figure shows the full extent of the Boreal Transition Zone in western Canada

the region is deep glacial till overlain primarily by luvisols. Study wetlands ranged in size from 0.4 to 746.8 ha with a median area of 29.8 ha. To achieve good spatial coverage in the western BTZ, shallow open water wetlands were randomly sampled among 5 sampling regions and stratified across a range of agricultural encroachment: eastern Peace Lowlands of British Columbia (EPL-BC; 55 $31^{\prime} \mathrm{N}, 120^{\circ} 13^{\prime} \mathrm{W}$ ), western Peace Lowlands of Alberta (WPL-AB; $56^{\circ} 14^{\prime} \mathrm{N}, 117^{\circ} 17^{\prime} \mathrm{W}$ ), eastern Peace Lowlands of Alberta (EPL-AB; $55^{\circ} 10^{\prime} \mathrm{N}, 118^{\circ}$ $49^{\prime} \mathrm{W}$ ), west central Alberta (WC-AB; $54^{\circ} 07^{\prime} \mathrm{N}, 114^{\circ} 24^{\prime} \mathrm{W}$ ), and east central Alberta (EC-AB; $\left.54^{\circ} 46^{\prime} \mathrm{N}, 111^{\circ} 58^{\prime} \mathrm{W}\right)$ (Fig. 1).

Environmental and Physical Data Area and perimeter of wetlands were acquired through the National Topographic Database (NTDB). Wetland morphometry data were cross referenced with recent aerial photographs and corrected for the present wetland area during helicopter-based waterfowl surveys which were conducted concurrent with this project (Ducks Unlimited Canada, unpubl. data). Land use data were obtained from the Prairie Farm Rehabilitation Administration (PFRA) GIS database which is based on Landsat imagery from 1995 (Government of Canada et al. 2001). Agricultural land use within a $1.6 \mathrm{~km}$ buffer surrounding all study wetlands was calculated based initially on the PFRA data. Subsequently, the estimated percentage of agriculturally impacted area within the buffer surrounding each basin was confirmed or updated during the 2005-07 helicopter-based waterfowl surveys. The $1.6 \mathrm{~km}$ buffer size from the wetland edge was based on the area adjacent to wetlands that would include most nesting waterfowl. No attempt was made to define basin-specific watersheds because much of Alberta is characterized by low relief and little surface runoff (Devito et al. 2005b). No wetlands have been altered by tile drainage, although ditching and channels are common in the some agricultural areas. While there may be some differences associated with surface runoff from cultivated, agricultural land and unimproved pasture (van der Kamp et al. 2003) or aspen forests in undeveloped BTZ lands, recent studies suggest that summer precipitation is more important to the wetland water budget than spring melt flows in areas with vegetated cover (Ferone and Devito 2004; Devito et al. 2005a; Redding and Devito 2011). The focus of our study is on the overall effect of agriculture on nutrient concentrations regardless of how nutrients arrive.

Historical climate data were obtained from the National Climate Data and Information Archive (Environment Canada 2007). Climate data from the Grande Prairie A weather station was the best representative of the BTZ and provided the most comprehensive climate history dating back to 1943 .

Some sites were sampled up to 3 times during the study period (August 2005-2007) resulting in a total of 326 wetland- 
year observations on 212 unique wetlands. Water depth, secchi depth and SAV were sampled. SAV coverage was visually estimated using a ranked scale of percent cover where $1=$ no plant cover, $2=$ rare plant cover $(<5 \%), 3=$ occasional plant cover $(5-25 \%), 4=$ common plant cover $(25-75 \%)$, and $5=$ abundant plant cover $(>75 \%)$. There is a strong and significant relationship between the ranked scale and biomass of SAV (Pearson $r=0.77, P<0.001, n=24$; Bayley et al. 2007). For this paper, SAV ranks 1 and 2 were combined into one category $(\mathrm{SAV}$ rank $1=\mathrm{SAV}<5 \%)$ as there were relatively few wetlands where SAV was absent, SAV rank $2=5-25 \%$, SAV rank $3=25-75 \%$, SAV rank $4=>75 \%$.

Water samples were collected from the center of each of wetland in mid-August 2005-2007. Water samples were collected from below the water surface and analyzed for chemical composition including: total phosphorus (TP), soluble reactive phosphorus (SRP), total dissolved phosphorus (TDP), total nitrogen (TN), total dissolved nitrogen (TDN), ammonium $\left(\mathrm{NH}_{4}{ }^{+}\right)$, nitrite + nitrate $\left(\mathrm{NO}_{2}{ }^{-}+\mathrm{NO}_{3}{ }^{-}\right)$, sodium $\left(\mathrm{Na}^{+}\right)$, potassium $\left(\mathrm{K}^{+}\right)$, calcium $\left(\mathrm{Ca}^{2+}\right)$, magnesium $\left(\mathrm{Mg}^{2+}\right)$, silica $\left(\mathrm{Si}^{+}\right)$, sulfate $\left(\mathrm{SO}_{4}{ }^{2-}\right)$, chloride $\left(\mathrm{Cl}^{-}\right)$, dissolved organic carbon (DOC), chla, alkalinity (alk), total dissolved solids (TDS) and color. All chemical analyses were conducted in the Biogeochemical Analytical Service Laboratory at the University of Alberta. Turbidity (NTU) was measured using a turbidimeter, while $\mathrm{pH}$, dissolved oxygen $\left(\mathrm{mg} \mathrm{L}^{-1}\right)$, and specific conductivity $\left(\mu \mathrm{S} \mathrm{cm}^{-1}\right)$ were measured in-situ using the Hydrolab Surveyor 4a (Hach Environmental, www.hydrolab.com).

Data Analyses The Hamon method was used to calculate potential evapotranspiration (PET) (Hamon 1961). Annual effective precipitation (P-PET) and growing season effective precipitation (May to August) was then calculated from 1943 to 2007. Annual effective precipitation decreased from $93.0 \mathrm{~mm}$ in 2004 to $-136.7 \mathrm{~mm}$ in 2005 (Fig. 2). The drying trend continued into 2006 with an annual effective precipitation of $-125.4 \mathrm{~mm}$. Two consecutive dry years (2005 and 2006) exacerbated already dry conditions in the BTZ leading to hydrologic conditions that were consistent with drought (cumulative growing season P-PET ${ }_{1943-2006}$ of $-2323.0 \mathrm{~mm}$ ). Conditions were marginally wetter in 2007 with an annual P-PET of $2.8 \mathrm{~mm}$ which raised the cumulative effective precipitation to $-2320.0 \mathrm{~mm}$ (Fig. 2). 2006 will be hereafter referred to as the dry year. The drying trend in Canada's western boreal forest has been on-going for several decades and is projected to continue as regional temperatures increase (Schindler and Donahue 2006). This has resulted in many shallow lakes becoming even shallower open water wetlands.

\section{Statistical Approach}

One of our goals was to disentangle the effects of the dry year, amount of agriculture in the buffer and regional differences in nutrients, chl $a$ and SAV in the study wetlands. In addition we wanted to determine the effect of SAV relative to agricultural encroachment on algal biomass $(\operatorname{chl} a)$ and TP. Our study was part of a larger study to determine the abundance and distribution of waterfowl in various regions of the BTZ and to examine the habitat and limnological features in a subset $(n=212)$ of those wetlands. Some wetlands were sampled multiple times and others were sampled only once during the 3 years resulting in 326 wetland-year observations. This made a complex sampling design in
Fig. 2 Cumulative precipitation-potential evapotranspiration (P-PET) and annual P-PET from 1943 to 2007 at the Grande Prairie Weather Station (Environment Canada historical climate database)

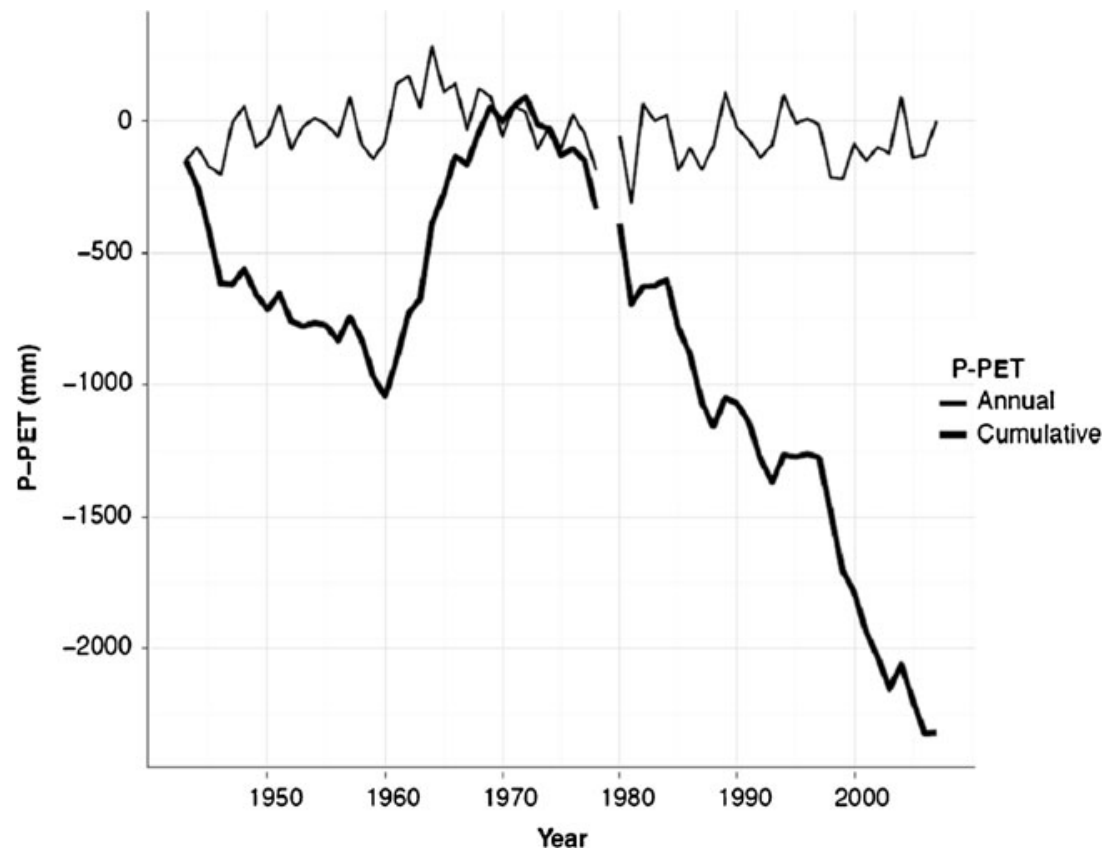


terms of years, regions and land use. This sampling design required the use of a mixed effect modeling approach to predict water quality as it relates to agricultural encroachment, regional and temporal effects. Linear mixed effect models with individual basins specified as the random effect were developed to account for repeated sampling of some wetlands (Crawley 2007). Data were log transformed prior to analyses to meet assumptions of normality and was assessed using diagnostic plots. An information theoretic approach was taken to develop models (Burnham and Anderson 2002). To examine the effect of agriculture and the dry year on nutrients and wetland condition, we developed a global model and a set of candidate models which included combinations of temporal, spatial and agriculture parameters (Supplemental Table A). Sampling year was treated as a fixed effect and a proxy for precipitation conditions where 2006 was determined to be the driest year. We examined the effect of agricultural encroachment, year sampled and sampling region on concentrations of TP, TN and chla, maximum depth, secchi depth, SAV, conductivity and silica. These variables were chosen as the best response variables because they represent the productivity and environmental conditions of these wetlands. To assess the role of SAV relative to agricultural effects on chl $a$ and TP, we developed a global model and a set of candidate models listed in Supplemental Table B. Akaike's Information criteria (AICc) and weights were calculated for model selection (Burnham and Anderson 2002). Top ranked models with $\Delta \mathrm{AICc}<2.0$ were averaged to produce model-averaged estimates of $\beta$ coefficients. Relative importance of covariates was calculated if they were present in 1 of the top ranked models. Multiple pairwise comparisons using a post-hoc Tukey statistic were used to compare differences in nutrient concentration and environmental variables among year, region and SAV rank. Analyses were performed in R 2.11.1 (R Development Core Team 2008) using packages nlme for linear mixed models (Pinheiro et al. 2011), AICcmodavg for AIC model selection, relative importance computation and model averaging (Mazerolle 2011), and multcomp for post-hoc Tukey multiple comparisons (Hothorn et al. 2008).

\section{Results}

Physical and Nutrient Characteristics of BTZ Wetlands

Wetlands were small (median $=29.8$ ha), shallow (median maximum depth $=1.0 \mathrm{~m}$ ) and supported considerable SAV beds (median coverage $=25-75 \%$ of the wetland; Table 1 ). Despite the eutrophic to hypereutrophic conditions (median $\mathrm{TP}=148.0 \mu \mathrm{g} \mathrm{L}^{-1}$ ), chl $a$ concentration remained low (median $\left.\operatorname{chl} a=15.5 \mu \mathrm{g} \mathrm{L}^{-1}\right)$ in these wetlands. Although average overall agricultural encroachment was approximately $50 \%$ within $1.6 \mathrm{~km}$ of the wetland edge (Table 1), agricultural encroachment varied among sampling regions with EPL-BC being least affected by land conversion (3.6\%) and WC-AB being most impacted (48.1\%). EC-AB, WPL-AB and EPL$\mathrm{AB}$ had average agricultural encroachment of $16.8 \%, 19.26 \%$ and $33.1 \%$ within $1.6 \mathrm{~km}$ of the wetland edge, respectively.

BTZ wetlands are also characterized by high concentrations of DOC, color, TDS and specific conductivity (Table 1) as well as moderately high concentrations of cations and anions (Table 1). Increasing agricultural encroachment also increased the concentrations of most anions $\left(\mathrm{Cl}^{-}, \mathrm{SO}^{2-}\right)$, alkalinity and cations $\left(\mathrm{Na}^{+}, \mathrm{K}^{+}, \mathrm{Mg}^{2+}\right)$ (data not shown).

Effect of Agriculture on Nutrients and Other Environmental Characteristics

Increasing agricultural encroachment increased concentrations of nutrients (TP, TN), conductivity and SAV abundance (Table 2, Fig. 3a). Contrary to our hypothesis agricultural encroachment did not significantly affect concentrations of chla (Fig. 3b) and silica (Table 2). Maximum depth and secchi depth were significantly shallower as agricultural encroachment increased in the buffer around a wetland (Fig. 4a, b). Limnological conditions and water clarity (TP, TN, chla, secchi depth, conductivity) varied regionally and temporally in BTZ wetlands, although maximum depth and SAV abundance did not vary by sampling region (Table 2). Wetlands were typically eutrophic, particularly in the Peace Lowlands of Alberta (WPL-AB $=101.3 \mu \mathrm{g}$ TP L ${ }^{-1}$, EPL-AB $=129.3 \mu \mathrm{g}$ TP $\mathrm{L}^{-1}$ ), shallow $(<1.5 \mathrm{~m})$ and $\mathrm{SAV}$ was generally common (rank $2-3=5-25 \%$ to $25-75 \%$; Table 3 ).

TP concentration was best explained by the extent of agricultural encroachment, sampling region, and year (Table 2). The dry year caused evapoconcentration of TP in wetlands which led to significantly greater TP concentrations in 2006 and 2007 (Fig. 3a, ANOVA; $F_{\text {Year }}=7.10, P<0.00$ ). Predicted TP concentration in 2006 and 2007 (65.7 and $72.6 \mu \mathrm{g} \mathrm{L}^{-1}$ respectively) was significantly greater than in 2005 (53.2 $\mu \mathrm{g} \mathrm{L}^{-1}$; Table 3). As expected, amount of agriculture in the buffer surrounding wetlands was a significant and positive influence on TP concentration due to enrichment through run-off of fertilizers, manure and other nutrient sources (Fig. 3a). TP also varied regionally with EPL-AB and WPL-AB regions having significantly richer waters than WC$\mathrm{AB}$ and EPL-BC (Table 3). Wetlands of the EPL-AB also had greater TP concentration than those in EC-AB (Table 3). Even when the positive effect of agriculture on TP is taken into account $\left(\beta_{\mathrm{ag}}=0.02, P<0.00\right)$, wetlands in the BTZ are still rich in TP. The study wetlands were naturally eutrophic, the predicted average TP concentration ranged from 44.6 to $129.3 \mu \mathrm{g} \mathrm{L}^{-1}$ with wetlands in EPL-BC being the least enriched and those in EPL-AB being the most enriched (Table 3). 
Table 1 Summary of limnological and physical characteristics of BTZ wetlands $(N=212)$. Wetlands sampled more than once were averaged prior to obtaining overall summary statistics

\begin{tabular}{|c|c|c|c|c|}
\hline Variable & Average & Median & Minimum & Maximum \\
\hline Wetland area (ha) & 71.96 & 29.81 & 0.38 & 746.81 \\
\hline Depth (m) & 1.07 & 0.84 & 0.03 & 6.68 \\
\hline Secchi (m) & 0.65 & 0.58 & 0.03 & 2.32 \\
\hline Maximum depth (m) & 1.31 & 1.00 & 0.03 & 6.68 \\
\hline SAV rank & $25-75 \%$ & $25-75 \%$ & $<5 \%$ & $>75 \%$ \\
\hline$\%$ agriculture & 41.12 & 44.25 & 0.00 & 100.00 \\
\hline Conductivity $\left(\mu \mathrm{S} \cdot \mathrm{cm}^{-1}\right)$ & 405.07 & 368.61 & 51.70 & 1541.34 \\
\hline $\mathrm{pH}$ & 8.97 & 9.05 & 6.56 & 12.32 \\
\hline $\mathrm{TP}\left(\mu \mathrm{g} \cdot \mathrm{L}^{-1}\right)$ & 283.96 & 147.95 & 12.63 & 3375.00 \\
\hline $\operatorname{SRP}\left(\mu \mathrm{g} \cdot \mathrm{L}^{-1}\right)$ & 133.17 & 13.12 & 1.00 & 2904.20 \\
\hline $\operatorname{TDP}\left(\mu \mathrm{g} \cdot \mathrm{L}^{-1}\right)$ & 200.34 & 68.92 & 5.01 & 3312.50 \\
\hline $\mathrm{TN}\left(\mu \mathrm{g} \cdot \mathrm{L}^{-1}\right)$ & 3518.28 & 3174.00 & 878.00 & 13560.00 \\
\hline $\mathrm{NH}_{4}^{+}\left(\mu \mathrm{g} \cdot \mathrm{L}^{-1}\right)$ & 100.20 & 49.10 & 1.00 & 1547.00 \\
\hline $\mathrm{NO}_{2}^{-}+\mathrm{NO}_{3}^{-}\left(\mu \mathrm{g} \cdot \mathrm{L}^{-1}\right)$ & 6.38 & 2.73 & 1.00 & 214.34 \\
\hline $\operatorname{TDN}\left(\mu \mathrm{g} \cdot \mathrm{L}^{-1}\right)$ & 2719.14 & 2568.33 & 737.00 & 8350.00 \\
\hline TN:TP & 27.44 & 20.30 & 1.44 & 110.32 \\
\hline available N: SRP & 12.83 & 4.81 & 0.02 & 693.50 \\
\hline Chla $\left(\mu \mathrm{g} \cdot \mathrm{L}^{-1}\right)$ & 52.05 & 15.50 & 0.37 & 1562.62 \\
\hline $\mathrm{DOC}\left(\mathrm{mg} \cdot \mathrm{L}^{-1}\right)$ & 42.70 & 38.31 & 10.20 & 127.70 \\
\hline $\mathrm{Cl}^{-}\left(\mathrm{mg} \cdot \mathrm{L}^{-1}\right)$ & 9.70 & 4.34 & 0.10 & 136.04 \\
\hline $\mathrm{SO}^{2-}\left(\mathrm{mg} \cdot \mathrm{L}^{-1}\right)$ & 54.63 & 8.21 & 0.05 & 508.46 \\
\hline $\mathrm{Na}^{+}\left(\mathrm{mg} \cdot \mathrm{L}^{-1}\right)$ & 22.24 & 13.77 & 0.00 & 173.40 \\
\hline $\mathrm{K}^{+}\left(\mathrm{mg} \cdot \mathrm{L}^{-1}\right)$ & 17.89 & 13.88 & 0.15 & 109.07 \\
\hline $\mathrm{Ca}^{2+}\left(\mathrm{mg} \cdot \mathrm{L}^{-1}\right)$ & 78.14 & 28.98 & 3.03 & 995.40 \\
\hline $\mathrm{Mg}^{2+}\left(\mathrm{mg} \cdot \mathrm{L}^{-1}\right)$ & 28.59 & 17.31 & 3.37 & 166.40 \\
\hline Silica $\left(\mathrm{mg} \cdot \mathrm{L}^{-1}\right)$ & 3.46 & 2.26 & 0.30 & 15.40 \\
\hline Alkalinity $\left(\mathrm{mg} \cdot \mathrm{L}^{-1}\right.$ as $\left.\mathrm{CaCO}_{3}\right)$ & 144.15 & 142.34 & 22.10 & 442.98 \\
\hline Bicarbonate $\left(\mathrm{mg} \cdot \mathrm{L}^{-1}\right)$ & 134.28 & 118.79 & 27.00 & 407.05 \\
\hline Color $\left(\mathrm{mg} \cdot \mathrm{L}^{-1}\right.$ as $\left.\mathrm{Pt}\right)$ & 111.64 & 98.70 & 9.60 & 439.65 \\
\hline $\operatorname{TDS}\left(\mathrm{mg} \cdot \mathrm{L}^{-1}\right)$ & 344.57 & 306.33 & 52.00 & 1647.50 \\
\hline
\end{tabular}

TN was also significantly affected by the dry year and agricultural encroachment (Table 2) and varied regionally. The dry year in 2006 increased concentration of $\mathrm{TN}$, but concentrations did not remain elevated in 2007 (Table 3). EPL-BC had the lowest concentration of TN in the BTZ (Table 3). Conductivity showed similar patterns where significant increases occurred in 2006 and the western regions of the BTZ (EPL-BC and WPL-AB) had significantly lower levels of conductivity than regions in the east (Table 3).
Table 2 AIC $_{\mathrm{c}}$ summary of models investigating agricultural, regional and yearly effects on limnological and physical characteristics of BTZ wetlands. Response variables were $\log (\mathrm{x}+1)$ transformed where necessary. Basin ID was treated as a random effect. Models with $\Delta \mathrm{AIC}_{\mathrm{c}}>2.0$ are not shown

\begin{tabular}{|c|c|c|c|c|c|}
\hline Response & Fixed effects & K & $\mathrm{AICc}$ & $\triangle \mathrm{AICc}$ & $\mathrm{w}_{i}$ \\
\hline $\mathrm{TP}$ & $\%$ agriculture + Year + Region & 10 & 760.18 & 0.00 & 0.99 \\
\hline $\mathrm{TN}$ & $\%$ agriculture + Year + Region & 10 & 383.66 & 0.00 & 0.99 \\
\hline \multirow[t]{2}{*}{ Chla } & Year + Region & 9 & 1086.07 & 0.00 & 0.72 \\
\hline & $\%$ agriculture + Year + Region & 10 & 1088.06 & 1.99 & 0.27 \\
\hline Maximum depth & $\%$ agriculture + Year & 6 & 629.21 & 0.00 & 0.83 \\
\hline Secchi depth & $\%$ agriculture + Year + Region & 10 & 542.80 & 0.00 & 0.97 \\
\hline SAV & $\%$ agriculture + Year & 6 & 892.88 & 0.00 & 0.92 \\
\hline Conductivity & $\%$ agriculture + Year + Region & 10 & 387.72 & 0.00 & 0.86 \\
\hline Silica & Year + Region & 9 & 668.61 & 0.00 & 0.73 \\
\hline
\end{tabular}



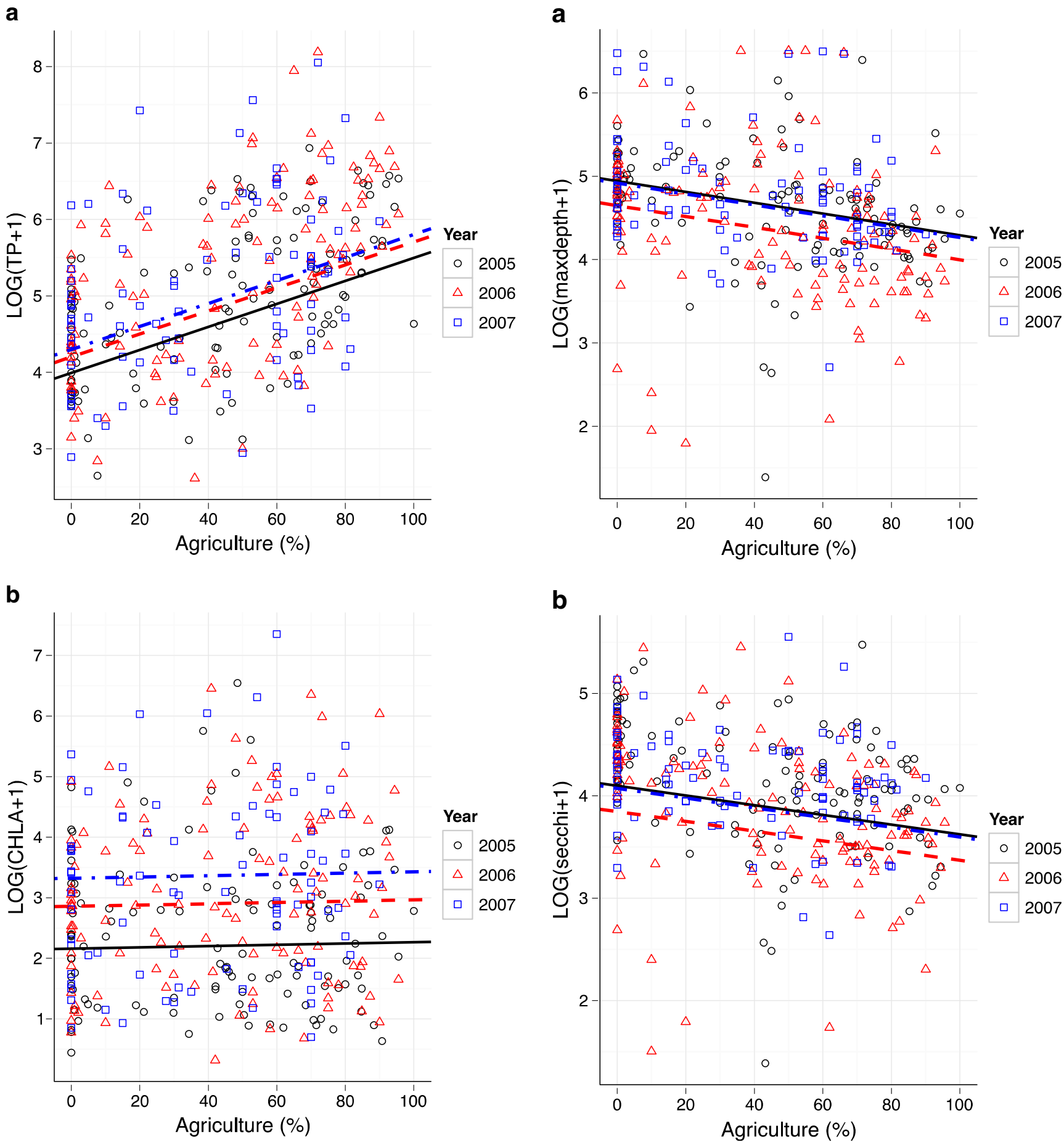

Fig. 3 Effect of agriculture on A. TP concentration $(\log (\mathrm{TP}+1) \sim \% \mathrm{ag}+$ year + sampling region, $\left.w_{i}=0.99 ; \beta_{\mathrm{ag}}=0.015, P<0.000\right)$ and $\mathrm{B}$. chla concentration $\left(\log (\mathrm{chla}+1) \sim \% \mathrm{ag}+\right.$ year + sampling region, $w_{i}=$ 0.27; $\left.\beta_{\mathrm{ag}}=0.001, P=0.71\right)$ over 3 years. Lines: $2005=$ solid, $2006=$ dash, $2007=$ long dash, short dash

Chla concentration was best explained by regional and temporal factors and there was no significant relationship between agriculture and chla concentration (Table 2, Fig. 3b). Chl $a$ concentration steadily and significantly increased over

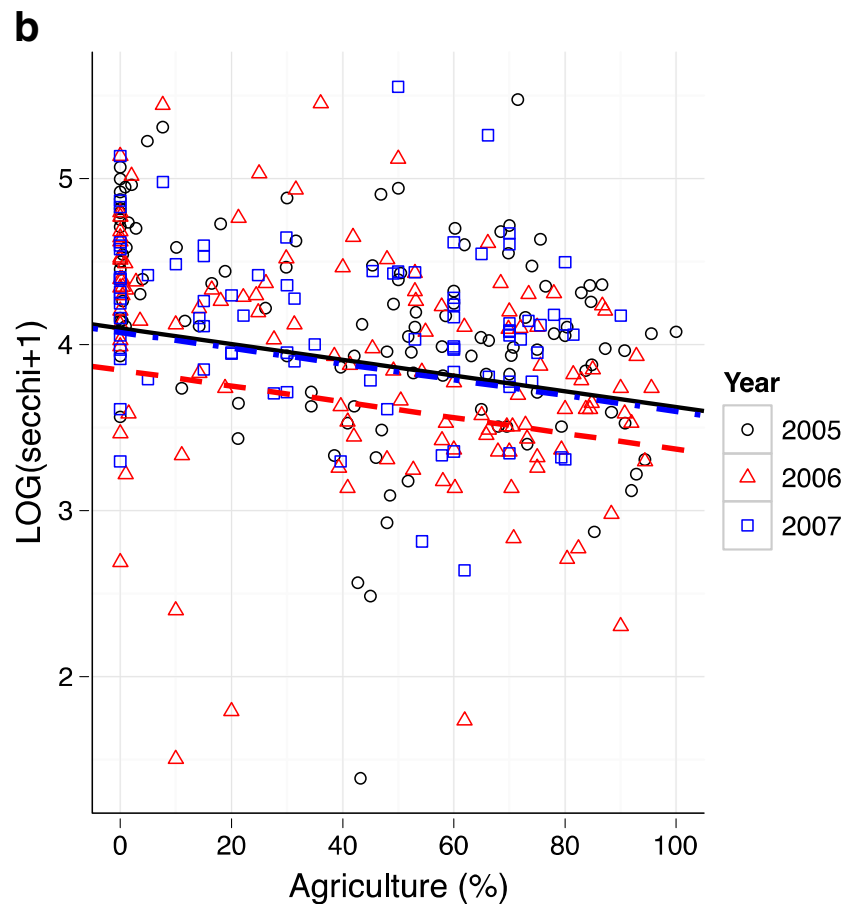

Fig. 4 Effect of agriculture on A. maximum depth $(\log (\operatorname{maxdepth}+1)$ $\sim \% \mathrm{ag}+$ year), $\left.w_{i}=0.83 ; \beta_{\mathrm{ag}}=-0.007, P<0.000\right)$ and $\mathrm{B}$. secchi depth $\left(\log (\right.$ secchi +1$) \sim \% \mathrm{ag}+$ year + sampling region, $w_{i}=0.97 ; \beta_{\mathrm{ag}}=-0.005$, $P<0.000)$ over 3 years. Lines: $2005=$ solid, $2006=$ dash, $2007=$ long dash, short dash

time (Table 3) and ranged from 8.2 to $28.3 \mu \mathrm{g} \mathrm{L}^{-1}$ over the 3 years. WPL-AB had significantly greater chl $a$ concentrations than EC-AB and EPL-BC (Table 3). Concentration of silica also follows a similar pattern as chla where agricultural 
Table 3 Model predicted averages of selected limnological and physical variables on BTZ lakes from the best supported models listed in Table 2. Predicted averages for each factor (Year, Sampling region) are what would be expected once the effects of the other covariates are considered. Predicted average values were obtained from backtransformed $\beta$ coefficients. Superscripts indicate multiple pairwise comparison post-hoc Tukey test results $(P<0.05)$ within year and sampling region

\begin{tabular}{|c|c|c|c|c|c|c|c|c|c|}
\hline \multirow[t]{2}{*}{ Variable } & \multicolumn{3}{|l|}{ Year } & \multicolumn{5}{|c|}{ Sampling region } & \multirow{2}{*}{$\begin{array}{l}\text { Effect of } \\
\text { agriculture }\left(\beta_{\mathrm{ag}}\right.\end{array}$} \\
\hline & 2005 & 2006 & 2007 & EPL-BC & WPL-AB & EPL-AB & WC-AB & $\mathrm{EC}-\mathrm{AB}$ & \\
\hline $\mathrm{TP}\left(\mu \mathrm{g} \mathrm{L}^{-1}\right)$ & $53.17^{\mathrm{a}}$ & $65.72^{\mathrm{b}}$ & $72.55^{\mathrm{b}}$ & $44.61^{\mathrm{a}}$ & $101.32^{\mathrm{bd}}$ & $129.27^{\mathrm{cd}}$ & $53.17^{\mathrm{a}}$ & $63.35^{\mathrm{ab}}$ & +0.02 \\
\hline $\mathrm{TN}\left(\mu \mathrm{g} \mathrm{L}^{-1}\right)$ & $2478.90^{\mathrm{a}}$ & $2942.77^{\mathrm{b}}$ & $2745.01^{\mathrm{ab}}$ & $1143.32^{\mathrm{a}}$ & $2364.89^{\mathrm{b}}$ & $2224.78^{\mathrm{b}}$ & $2478.90^{\mathrm{b}}$ & $2359.89^{\mathrm{b}}$ & +0.005 \\
\hline Conductivity $\left(\mu \mathrm{S} \cdot \mathrm{cm}^{-1}\right)$ & $272.80^{\mathrm{a}}$ & $307.69^{\mathrm{b}}$ & $298.80^{\mathrm{ab}}$ & $142.21^{\mathrm{a}}$ & $200.11^{\mathrm{b}}$ & $317.64^{\mathrm{c}}$ & $272.80^{\mathrm{c}}$ & $291.07^{\mathrm{c}}$ & +0.06 \\
\hline $\operatorname{Chl} a\left(\mu \mathrm{g} \mathrm{L}^{-1}\right)$ & $8.18^{\mathrm{a}}$ & $17.45^{\mathrm{b}}$ & $28.25^{\mathrm{c}}$ & $4.47^{\mathrm{a}}$ & $16.07^{\mathrm{b}}$ & $11.13^{\mathrm{ab}}$ & $8.18^{\mathrm{ab}}$ & $6.29^{\mathrm{a}}$ & - \\
\hline Silica $\left(\mathrm{mg} \mathrm{L}^{-1}\right)$ & $1.66^{\mathrm{a}}$ & $2.35^{\mathrm{b}}$ & $2.59^{\mathrm{b}}$ & $2.02^{\mathrm{ab}}$ & $1.22^{\mathrm{a}}$ & $1.03^{\mathrm{a}}$ & $1.66^{\mathrm{ab}}$ & $2.53^{\mathrm{b}}$ & - \\
\hline Maximum depth (m) & $1.39^{\mathrm{a}}$ & $1.03^{\mathrm{b}}$ & $1.36^{\mathrm{a}}$ & - & - & - & - & - & -0.07 \\
\hline Secchi depth (m) & $59.30^{\mathrm{a}}$ & $45.77^{\mathrm{b}}$ & $57.73^{\mathrm{a}}$ & $109.39^{\mathrm{a}}$ & $71.85^{\mathrm{b}}$ & $76.22^{\mathrm{ab}}$ & $59.30^{\mathrm{a}}$ & $75.55^{\mathrm{ab}}$ & -0.05 \\
\hline SAV rank & $2.80^{\mathrm{a}}$ & $2.92^{\mathrm{a}}$ & $2.36^{\mathrm{b}}$ & - & - & - & - & - & +0.05 \\
\hline
\end{tabular}

encroachment did not affect silica concentration and concentration significantly increased from 1.7 to $2.6 \mu \mathrm{g} \mathrm{L}^{-1}$ over the 3 years (Table 3 ). Contrary to regional patterns of chla, silica concentration was significantly higher in EC-AB than in WPL$\mathrm{AB}$ and EPL-AB (Table 3).

Wetlands under greater agricultural encroachment tended to be shallower than those less impacted by agriculture and were negatively influenced by drought (Fig. 4a). Maximum depth did not significantly vary among regions, however the short-term temporal effect of the dry year was apparent (Fig. 4a; Table 3). Maximum depth returned to 2005 levels in 2007. Secchi depth varied temporally and regionally and was significantly and negatively affected by agricultural disturbance (Table 2). Effects of the dry year were temporary because secchi depth (as a surrogate for water clarity) significantly decreased in 2006 but recovered to 2005 levels by 2007 (Table 3, Fig. 4b). EPL-BC had significantly clearer water (greatest secchi depth) than WC-AB and WPL-AB (Table 3).

SAV abundance was best explained by agriculture and temporal effects (Table 2). There was a significant decrease in SAV in 2007 compared to the previous 2 years (Table 3), however, SAV still covered 5-25\% of most wetland basins (average rank 2.36). Regional differences in SAV were not significant indicating that SAV was able to grow abundantly throughout the BTZ (SAV rank 3.0= $25-75 \%$ cover).
The Effect of SAV Relative to Agricultural Encroachment on Chla and TP

To further examine how SAV might affect chla and TP concentrations, a SAV covariate was added to the best supported model for TP (Table 2) and SAV + TP covariates were added to the best supported models for chla (Table 2). $\mathrm{SAV}$, year, sampling region and agricultural encroachment were important in explaining TP concentration (Table 4). The addition of the SAV covariate improved the model substantially (w $i=0.89$ with $\mathrm{SAV} ; \mathrm{w}_{i}=0.11$ without SAV). Agriculture had a positive effect on TP concentration $\left(\beta_{\mathrm{ag}}=\right.$ $0.02, P<0.00)$. In addition, the predicted average of TP significantly increased during the dry year and remained elevated in 2007 (Table 5). TP concentration varied regionally where WPL-AB and EPL-AB were significantly richer in TP than EC-AB, EPL-BC, and WC-AB (Table 5). SAV had a significantly negative influence on TP concentration and was able to suppress TP at SAV densities greater than $75 \%$ (Table 5). Predicted average concentration of TP was significantly lower in wetlands with abundant SAV $(>75 \%)$ than in wetlands with less SAV coverage $(<25 \%$; Table 5).

The best supported model to predict chla concentration included SAV, TP concentration, year, agriculture and sampling region (Table 4). The relationship between chla and TP was highly significant (Table $\left.6 ; \beta_{\mathrm{TP}}=0.73, P<0.00\right)$ and chla
Table 4 AICc summary of nutrient models examining the effects of SAV and agriculture (\%ag) on TP and Chla. Models with $\Delta \mathrm{AIC}_{\mathrm{c}}>2.0$ are not shown

\begin{tabular}{llllll}
\hline Response variable & Model Specification & K & AICc & sAICc & wi \\
\hline TP & SAV + Year + \%ag + Region & 13 & 747 & 0.00 & 0.89 \\
Chla & SAV + Year + \%ag + Region + TP & 14 & 961.28 & 0.00 & 0.53 \\
& SAV + Year + \%ag + TP & 10 & 961.52 & 0.25 & 0.47 \\
\hline
\end{tabular}


Table 5 Model predicted average of TP concentrations by SAV abundance, year, and sampling region. The effect of agriculture was significant $\left(\beta_{\mathrm{ag}}=0.02, P<0.000\right)$. Predicted averages for each factor (SAV, Year and Sampling region) are what would be expected once effects of other covariates are considered. Superscripts indicate significant pairwise differences from multiple comparison post-hoc Tukey tests $(P<$ 0.05 ) within each factor

\begin{tabular}{llrrl}
\hline Predictor & & $\mathrm{TP}\left(\mu \mathrm{g} \cdot \mathrm{L}^{-1}\right)$ & $\mathrm{SE}$ & $\begin{array}{l}\text { post-hoc } \\
\text { Tukey test }\end{array}$ \\
\hline SAV & $<5 \%$ & 61.76 & 0.23 & $\mathrm{ab}$ \\
& $5-25 \%$ & 59.03 & 0.14 & $\mathrm{a}$ \\
& $25-75 \%$ & 53.34 & 0.15 & $\mathrm{ab}$ \\
& $>75 \%$ & 43.43 & 0.15 & $\mathrm{~b}$ \\
Year & 2005 & 61.76 & 0.23 & $\mathrm{a}$ \\
& 2006 & 77.27 & 0.07 & $\mathrm{~b}$ \\
Sampling region & EPL-BC & 53.73 & 0.29 & $\mathrm{ac}$ \\
& WPL-AB & 120.45 & 0.21 & $\mathrm{~b}$ \\
& EPL-AB & 154.45 & 0.25 & $\mathrm{~b}$ \\
& WC-AB & 61.76 & 0.23 & ac \\
& EC-AB & 74.27 & 0.19 & $\mathrm{a}$ \\
\hline
\end{tabular}

concentration significantly increased with year (ANOVA, $\left.F_{\text {Year }}=16.01, P<0.00\right)$. We expected chla concentrations to increase with increasing agricultural encroachment because $\mathrm{TP}$ has a significantly positive effect on chl $a\left(\beta_{\mathrm{TP}}=0.7, P<\right.$ 0.00 , model not shown) and there was a positive relationship between TP and agriculture $\left(\beta_{\text {ag }}=0.02, P<0.00\right.$, Fig. 3a). The lack of any agricultural effect on chla concentration was unexpected (Fig. 3b). Although agriculture was retained as a predictor in the best model, agricultural encroachment had an unexpected weak negative effect on chl $a$ concentration $\left(\beta_{\mathrm{ag}}=\right.$ $-0.01, P=0.00)$. SAV clearly suppressed chl $a$ concentration when SAV was abundant. Wetlands with $>75 \%$ SAV coverage had significantly reduced chl $a$ concentrations compared to wetlands with less than $5 \%$ SAV, 5-25\% SAV and 25-75\% SAV abundance (Table 6). Even wetlands with 25-75 \% SAV had significantly lower chla concentrations than wetlands with SAV $<5 \%$ (Table 6). Chla concentration did not vary by sampling region, however chla significantly increased in the dry year and remained elevated in 2007 (Table 6).

\section{Discussion}

Effects of Agriculture on Nutrient Concentrations and Sediment in BTZ Wetlands

Increased soil loss due to wind and water erosion in agricultural landscapes can increase sedimentation in wetlands with annual inputs of sediment being largely a function of soil texture, slope, size and land use (Skagen et al. 2008).
Table 6 Best supported model averaged summary statistics to predict chla concentrations. Superscripts indicate significant pairwise differences from multiple comparison post-hoc Tukey tests $(P<0.05)$ within each factor

\begin{tabular}{llrll}
\hline Predictor & & $\beta$ coefficient & SE & $\begin{array}{l}\text { Post-hoc } \\
\text { Tukey test }\end{array}$ \\
\hline SAV & $<5 \%$ & -0.24 & 0.39 & a \\
& $5-25 \%$ & -0.57 & 0.21 & ab \\
& $25-75 \%$ & -0.86 & 0.21 & $\mathrm{~b}$ \\
Year & $>75 \%$ & -1.24 & 0.20 & $\mathrm{c}$ \\
& 2005 & -0.24 & 0.39 & $\mathrm{a}$ \\
& 2006 & 0.29 & 0.13 & $\mathrm{~b}$ \\
Agriculture (\%) & 2007 & 0.44 & 0.19 & $\mathrm{~b}$ \\
TP & & -0.01 & 0.00 & \\
\hline
\end{tabular}

Annual rates of sediment accumulation of 4-9 $\mathrm{mm}$ per year have been measured in fine and medium-grained soils in arid, semi-arid and subhumid regions (Skagen et al. 2008). In our study, wetlands surrounded by a greater percentage of agriculture were shallower than wetlands surrounded primarily by native land cover (Fig. 4a). If we assume $7 \mathrm{~mm}$ per year sediment input (Skagen et al. 2008) over approximately 60 years since land clearing, there could have been a $42 \mathrm{~cm}$ loss of depth in the agriculturally affected wetlands, which is the approximate difference in depth between agriculturally impacted and undisturbed wetlands in the BTZ. Continued sedimentation from agricultural activities along with climate warming will exacerbate ongoing loss of shallow wetlands from drainage and infilling in the BTZ region.

Wetlands surrounded primarily by agriculture also had significantly higher concentrations of nutrients (TN, TP), decreased secchi and increased SAV abundance. Houlahan and Findlay (2004) found that nutrient levels were negatively correlated with forest cover at over $2 \mathrm{~km}$ from the wetland edge in eastern Canada, although in the boreal plain in western Canada, groundwater discharge appears to be more important than surface runoff to small wetlands (Devito et al. 2005a; Redding and Devito 2011). Increases in TP, TN, chl $a$ and total suspended solids are often associated with intensification of agriculture. Numerous studies have detected increased nutrient concentrations associated with increased agricultural land use (Egertson et al. 2004) and even isolated depressional lakes with little surface runoff show increased nutrient concentrations in water and sediment (Neely and Baker 1989; Whigham and Jordan 2003). Our study supports the findings of previous studies showing a significant positive relationship between agricultural encroachment and concentrations of TP and TN in wetlands and shallow lakes. Despite significant increases in total and available concentrations of $\mathrm{N}$ and $\mathrm{P}$ in wetlands surrounded by a high percentage of agriculture, chla surprisingly did not increase, but marginally 
decreased even though chla itself was highly influenced by TP (Table 6).

Effect of SAV Relative to Agriculture on Chlorophyll a Concentrations

SAV in BTZ wetlands surrounded by high agriculture was not light-limited due to their relatively shallow depth and high water transparency. The maximum depth of SAV colonization is largely dependent on availability of light (Canfield et al. 1985) and SAV in this region typically does not grow at depths greater than $1.75 \mathrm{~m}$ (Bayley unpublished data). BTZ wetlands have lower chla concentrations and contained high SAV densities despite the high nutrient concentrations associated with agriculture. After controlling for temporal variation, TP and agriculture effects, chl $a$ concentration was significantly lower in basins with SAV coverage above $25 \%$ compared to basins with less than $5 \%$ SAV (Table 6). Other research have shown that prairie wetlands with high salinity (TDS $>1,000 \mathrm{mgL}^{-1}$ ), may limit nutrient availability to chla thus explaining low chla growth in hypereutrophic conditions (Waiser and Robarts 1995; Evans and Prepas 1996), however the majority of BTZ wetlands studied were not saline (TDS $<947 \mathrm{mgL}^{-1}$ ) except for 2 wetlands with TDS between 1,000 and 1,200 $\mathrm{mgL}^{-1}$ and one wetland that was considered to be brackish with TDS of $1,648 \mathrm{mgL}^{-1}$. While it remains unclear what controls the growth of chla in our shallow wetlands, we suggest that SAV is a very important factor relative to agricultural encroachment in regulating algal productivity as well as TP concentrations in BTZ wetlands. Abundance and density of SAV has been found to dampen or buffer the effect of TP on chla in northern wetlands of the Boreal Plain (Bayley et al. 2007). SAV persisted for at least 3 years under the high nutrient conditions in BTZ wetlands, which is contrary to other findings where SAV disappears with eutrophication (Blindow 1992). For example, SAV coverage has been found to decline with increasing TP especially within the range of 50-200 $\mu \mathrm{g}$ $\mathrm{L}^{-1}$ and $\mathrm{TN}$ above $1,000-2,000 \mu \mathrm{gL}^{-1}$ (Kosten et al. 2009). However, it is likely that this clear, high SAV state in our BTZ wetlands is not stable and unlikely to persist especially if nutrients remain high or water levels increase. Ultimately, increasing water depths may change light penetration leading to increased algal growth which may switch BTZ wetlands to a turbid, low SAV state.

This study underscores the importance of SAV communities in maintaining water clarity and suppressing algal populations through top-down cascade mechanisms such as providing habitat for zooplankton which graze on algae, reducing re-suspension of sediments, competing with phytoplankton directly for nutrients and light, or indirectly via allelopathic relationships (Scheffer et al. 1993; Hilt and Gross 2008).

\section{Controls on SAV Abundance}

$\mathrm{N}$ and $\mathrm{P}$ were very high in shallow BTZ wetlands and exceed many of the previously proposed nutrient thresholds for SAV dominance. In our agriculturally affected wetlands [and the natural boreal wetlands sampled by Bayley et al. (2007)], total nitrogen values above $2.0 \mathrm{mgN} \mathrm{L}^{-1}$ did not inhibit growth of abundant SAV as has been found in Europe (Gonzalez Sagrario et al. 2005). While generally both TN and TP concentrations are high in our sites, the available $\mathrm{N}$ to SRP ratios are quite low (3.66:1, Table 1) suggesting that the available $\mathrm{N}$ species are low and potentially limiting to algal growth. Given that sediments of BTZ wetlands and shallow lakes are rich in both $\mathrm{N}$ and $\mathrm{P}$ (Bayley unpublished data), it is likely that SAV is more limited by water clarity than by nutrients.

Contrary to previous studies that report a switch to turbid regimes and loss of SAV with increased eutrophication (Blindow 1992; Egertson et al. 2004), BTZ wetlands with high TP concentrations and high agricultural impacts did not exhibit a detectable loss of SAV between 2005 and 2006. There was a small decrease in SAV abundance in 2007 when water levels rose; however SAV still covered at least 5-25\% of most wetland basins (Table 3). SAV generally remained abundant and chla concentration remained below or at the threshold of 18-20 $\mu \mathrm{g} \mathrm{L}^{-1}$ that defines turbid regimes in the southern boreal and prairie regions (Bayley and Prather 2003; Bayley et a1. 2007; Zimmer et al. 2009). Furthermore, SAV cover was within the $25-75 \%$ range $($ rank $=3.0)$ in wetlands with high agricultural encroachment. Other studies have also found that when shallow wetlands are not light limited, SAV is able to grow abundantly and persist throughout the wetland (Mjelde and Faafeng 1997; Kosten et al. 2009) despite higher nutrient loads.

Wetlands can have complex interactions between SAV, chl $a$ and TP that affect the chla -TP relationship (Bayley et al. 2007). Wetlands can exhibit alternative regimes including a clear SAV-dominated state or a turbid algal-dominated state when TP concentrations range between 50 and $250 \mu \mathrm{g} \mathrm{L}^{-1}$ (Gonzalez Sagrario et al. 2005; Kosten et al. 2009). However, SAV dominates many of our study wetlands even though median TP is $148.0 \mu \mathrm{g} \mathrm{L}^{-1}$. While excessive TP can promote the growth of algae which leads to high turbidity, low light penetration and loss of SAV (Scheffer et al. 1993), SAV appears to persist with much higher concentrations of phosphorus and nitrogen (Bayley and Prather 2003; Bayley et al. 2007; Kosten et al. 2009). In pristine boreal wetlands, SAV can weaken the overall impact of TP on chla concentrations and in relatively undisturbed wetlands containing $>75 \%$ SAV coverage there is no significant effect of TP on chla concentrations (Bayley et al. 2007). In our study, there is also evidence that 
high abundance of SAV ( $>75 \%$ coverage of the lake) can suppress TP; that is TP concentrations are significantly lower in lakes with SAV $>75 \%$ than in lakes with 5-25\% SAV (Table 5). This may be due to uptake of TP by the submersed vegetation (Dierberg et al. 2002). This ability to cope with elevated concentrations of phosphorus also may be partially due to frequent fish kills in shallow lakes which affects topdown control mechanisms (Zimmer et al. 2001). The lack of fish allows for stronger grazing pressure on phytoplankton by zooplankton and lower amounts of phytoplankton reduces shading of macrophytes (Zimmer et al. 2001; Norlin et al. 2005). Excess nitrogen, that is nitrogen levels exceeding $2.0 \mathrm{mgN} \mathrm{L}^{-1}$ can also limit SAV growth and even cause SAV to disappear (Gonzalez Sagrario et al. 2005; Kosten et al. 2009). Despite average TN values exceeding $3.2 \mathrm{mgN} \mathrm{L}^{-1}$ over 3 years, as well as TP values exceeding $148.0 \mu \mathrm{g} \mathrm{P} \mathrm{L}^{-1}$, SAV continued to cover $>25 \%$ and often $>75 \%$ of the open water area in most BTZ wetlands. This suggests that there is no consistent TP threshold determining SAV loss and that other climatic (water depth and clarity) and/or food-web interactions such as fish presence and their control on grazing zooplankton may also be important.

Our results support our hypothesis that agricultural encroachment increases nutrient concentrations in surface waters however there was no evidence of a positive relationship between agricultural encroachment and chl $a$. Our results suggest that SAV plays a significant role in maintaining clear water states by its ability to suppress concentrations of chla and TP. However, it is unlikely that shallow BTZ wetlands can persist over the long-term in a SAV-dominated state. Factors such as climate and continuation of the long-term drying trend along with increased sedimentation from agricultural activities will cause wetlands to transition more rapidly toward terrestrial systems or become increasingly isolated from inflows/outflows. Additionally, continued eutrophication from surrounding land use or nutrient release from senescing and decomposing SAV may affect persistence of the clear, SAVdominated regime. The dynamic climatic environment in the southern Boreal Plains, increasing agricultural expansion as well as the lack of clear regulatory protection for wetlands in western Canada and the instability of stable states suggests that these wetlands and their biota, especially the millions of waterfowl which use them, are facing great uncertainty in the future.

Acknowledgements We would like to thank Alberta North American Waterfowl Management Plan Partnership, Ducks Unlimited Canada, Alberta Conservation Association, and NSERC for financial assistance with this project. We also thank C. Silver, A. Kobryn, M. Kobryn, J. Leendertse for field assistance and M. Ranger, T. Morgan, L. Armstrong, N. Hopkins, and S. Dunn for statistical and GIS assistance.

Open Access This article is distributed under the terms of the Creative Commons Attribution License which permits any use, distribution, and reproduction in any medium, provided the original author(s) and the source are credited.

\section{References}

Bayley S, Prather C (2003) Do wetland lakes exhibit alternative stable states? Submersed aquatic vegetation and chlorophyll in western boreal shallow lakes. Limnol Oceanogr 48:2335-2345

Bayley S, Creed I, Sass G, Wong A (2007) Frequent regime shifts in trophic states in shallow lakes on the Boreal Plain: alternative "unstable" states? Limnol Oceanogr 52:2002-2012

Blindow I (1992) Long-term and short-term dynamics of submerged macrophytes in 2 shallow eutrophic lakes. Freshw Biol 28:15-27

Burnham KP, Anderson DR (2002) Model selection and multi-model inference: a practical information-theoretic approach. Springer, NY

Canfield DE, Langeland KA, Linda SB, Haller WT (1985) Relations between water transparency and maximum depth of macrophyte colonization in lakes. J Aquat Plant Manag 23:25-28

Carpenter S, Caraco N, Correll D, Howarth R, Sharpley A, Smith V (1998) Nonpoint pollution of surface waters with phosphorus and nitrogen. Ecol Appl 8:559-568

Crawley MJ (2007) The R book. Wiley, Chichester

Dahl TE, Watmough MD (2007) Current approaches to wetland status and trends monitoring in prairie Canada and the continental United States of America. Can J Remote Sens 33:S17-S27

Detenbeck NE, Elonen CM, Taylor DL, Cotter AM, Puglisi FA, Sanville WD (2002) Effects of agricultural activities and best management practices on water quality of seasonal prairie pothole wetlands. Wetl Ecol Manag 10:335-354

Devito K, Creed I, Fraser C (2005a) Controls on runoff from a partially harvested aspen-forested headwater catchment, Boreal Plain, Canada. Hyrdol Process 19:3-25

Devito K, Creed I, Gan T, Mendoza C, Petrone R, Silins U, Smerdon B (2005b) A framework for broad-scale classification of hydrologic response units on the Boreal Plain: is topography the last thing to consider? Hydrol Process 19:1705-1714

Dierberg F, DeBusk T, Jackson S, Chimney M, Pietro K (2002) Submerged aquatic vegetation-based treatment wetlands for removing phosphorus from agricultural runoff: response to hydraulic and nutrient loading. Water Res 36:1409-1422

Egertson C, Kopaska J, Downing J (2004) A century of change in macrophyte abundance and composition in response to agricultural eutrophication. Hydrobiologia 524:145-156

Environment Canada (2007) National Climate Data Archives for Grande Prairie, Alberta. http://www.climate.weatheroffice.gc.ca/ climateData/canada_e.html

Evans JC, Prepas EE (1996) Potential effects of climate change on ion chemistry and phytoplankton communities in prairie saline lakes. Limnol Oceanogr 41:1063-1076

Ferone J, Devito K (2004) Shallow groundwater-surface water interactions in pond-peatland complexes along a Boreal Plains topographic gradient. J Hydrol 292:75-95

Fitzsimmons M (2002) Estimated rates of deforestation in two boreal landscapes in central Saskatchewan, Canada. Can J For Res 32:843-851

Gonzalez Sagrario M, Jeppesen E, Goma J, Sondergaard M, Jensen J, Lauridsen T, Landkildehus F (2005) Does high nitrogen loading prevent clear-water conditions in shallow lakes at moderately high phosphorus concentrations? Freshw Biol 50:27-41

Government of Canada, Agriculture and Agri-Food Canada, Prairie Farm Rehabilitation Administration (2001) PFRA Generalized landcover for the Canadian Prairies. Dataset release date June 7, 2001

Hamon W (1961) Estimating potential evapotranspiration. Proc Am Soc Civ Eng 87:107-120

Harmel RD, Potter S, Casebolt P, Reckhow K, Green CH, Haney RL (2006) Compilation of measured nutrient load data for agricultural land uses in the US. J Am Water Resour Assoc 42:1163-1178 
Hilt S, Gross E (2008) Can allelopathically active submerged macrophytes stabilize clear-water states in shallow lakes? Basic Appl Ecol 9:422-432

Hobson K, Bayne E, Van Wilgenburg SL (2002) Large-scale conversion of forest to agriculture in the Boreal Plains of Saskatchewan. Conserv Biol 16:1530-1541

Hothorn T, Bretz F, Westfall P, Heiberger R, Schuetzenmeister A (2008) multcomp: Simultaneous inference in general parametric models. Biom J 50:346-363

Houlahan J, Findlay C (2004) Estimating the "critical" distance at which adjacent land-use degrades wetland water and sediment quality. Landsc Ecol 19:677-690

Jackson L (2003) Macrophyte-dominated and turbid states of shallow lakes: evidence from Alberta Lakes. Ecosystems 6:213-223

Jeppesen E, Jensen JP, Jensen C et al (2003) The impact of nutrient state and lake depth on top-down control in the pelagic zone of lakes: a study of 466 lakes from the temperate zone to the Arctic. Ecosystems 6:313-325

Kosten S, Kamarainen A, Jeppesen E et al (2009) Climate-related differences in the dominance of submerged macrophytes in shallow lakes. Glob Chang Biol 15:2503-2517

Kratz T, Webster K, Bowser C, Magnuson J, Benson B (1997) The influence of landscape position on lakes in northern Wisconsin. Freshw Biol 37:209-217

Macrae M, Redding T, Creed I, Bell W, Devito K (2005) Soil, surface water and ground water phosphorus relationships in a partially harvested Boreal Plain aspen catchment. For Ecol Manag 206:315-329

Mazerolle MJ (2011) AICcmodavg: model selection and multimodel inference based on (Q)AIC(c). http://CRAN.R-project.org/ package $=$ AICcmodavg

Mjelde M, Faafeng B (1997) Ceratophyllum demersum hampers phytoplankton development in some small Norwegian lakes over a wide range of phosphorus concentrations and geographical latitude. Freshw Biol 37:355-365

National Wetlands Working Group (1997) The Canadian Wetland Classification System, 2nd edition, Warner BG, Rubec CDA (eds.), Wetlands Research Centre, University of Waterloo, Waterloo, ON, Canada

Neely R, Baker J (1989) Nitrogen and phosphorus dynamics and the fate of agricultural runoff. In: Northern Prairie Wetlands. Iowa State University Press, Ames, Iowa, USA, pp 92-131

Norlin J, Bayley S, Ross L (2005) Submerged macrophytes, zooplankton and the predominance of low- over high-chlorophyll states in western boreal, shallow-water wetlands. Freshw Biol 50:868-881

Pinheiro J, Bates D, DebRoy S, Sarkar D, R Development Core Team (2011) nlme: linear and nonlinear mixed effects models. R package version 3.1-102

Prepas E, Planas D, Gibson J et al (2001) Landscape variables influencing nutrients and phytoplankton communities in Boreal Plain lakes of northern Alberta: a comparison of wetland- and uplanddominated catchments. Can J Fish Aquat Sci 58:1286-1299

R Development Core Team (2008) R: a language and environment for statistical computing. Vienna, Austria. http://www.R-project.org

Redding T, Devito K (2011) Aspect and soil textural controls on snowmelt runoff on forested Boreal Plain hillslopes. Hydrol Res 42:250-267

Scheffer M, Hosper S, Meijer M, Moss B, Jeppsen E (1993) Alternative equilibria in shallow lakes. Trends Ecol Evol 8:275-279

Schindler D (2006) Recent advances in the understanding and management of eutrophication. Limnol Oceanogr 51:356-363

Schindler D, Donahue W (2006) An impending water crisis in Canada's western prairie provinces. Proc Natl Acad Sci U S A 103:7210-7216

Skagen S, Melcher C, Haukos D (2008) Reducing sedimentation of depressional wetlands in agricultural landscapes. Wetlands 28:594-604

Turner B, Hochbaum G, Caswell F, Neiman D (1987) Agricultural impacts on wetland habitats on the Canadian Prairies 1981-85. Transactions of the North American Wildlife and Natural Resources Conference: 206-215

van der Kamp G, Hayashi M, Gallen D (2003) Comparing the hydrology of grassed and cultivated catchments in the semi-arid Canadian prairies. Hydrol Process 17:559-575

Verhoeven J, Arheimer B, Yin C, Hefting M (2006) Regional and global concerns over wetlands and water quality. Trends Ecol Evol 21:96-103

Waiser MJ, Robarts RD (1995) Microbial nutrient limitation in prairie saline lakes with high sulfate concentration. Limnol Oceanogr 40:566-574

Watmough, M, Ingstrup D, Duncan D, Schinke H (2002) Prairie Habitat Joint Venture habitat monitoring program. Phase 1: Recent habitat trends. Canadian Wildlife Service, Edmonton, Alberta, Canada

Watmough M, Schmoll M (2007) Environment Canada's Prairie and Northern Region Habitat Monitoring Program Phase II: recent habitat trends in the Prairie Habitat Joint Venture. Environment Canada, Canadian Wildlife Service, Edmonton

Whigham D, Jordan T (2003) Isolated wetlands and water quality. Wetlands 23:541-549

Zedler J, Kercher S (2005) Wetland resources: status, trends, ecosystem services, and restorability. In: Annual Review of Environment and Resources. Annual Reviews, Palo Alto, pp 39-74

Zimmer K, Hanson M, Butler MG (2001) Effects of fathead minnow colonization and removal on a prairie wetland ecosystem. Ecosystems 4:346-357

Zimmer K, Hanson M, Herwig B, Konsti M (2009) Thresholds and stability of alternative regimes in shallow prairie-parkland lakes of central North America. Ecosystems 12:843-852 